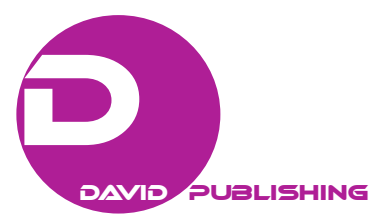

\title{
The Study of Religion in the Early Christian Literature
}

\author{
Georgios Gaitanos \\ College University Logos, Tirana, Albania
}

\begin{abstract}
This paper aims to search if there was any attempt in the Early Christian Literature to apply a scientific or a regulated study of religion. A special interest through the interpretation and analysis of those texts comes up with the procedure of Clement of Alexandria and Lactantius, when they tried to study the subject "religion". The first one promoted an evolutionary line for the development of religion in the world and as a result Christianity was the pick of this evolution. However, the second one mentioned the uniqueness of the truth only in the Christian faith, deconstructing the rest of the cults and attaching to the authenticity of Christianity holy and ontological characteristics that do not have any connection with the human culture. The goal of the paper is to mention if there was any sy stematic study of religion in the Early Christian writers and the author comes up with the conclusion that these two ecclesiastic writers promoted and initiated a new meaning to the terminology "religion", differentiating themselves from the general point of view, as they started referring to religion as a concept and not just as an action of worship or a specific religious tradition.
\end{abstract}

Keywords: scientific study of religion, Clement of Alexandria, Lactantius, vera-falsa religio, superstitio

\section{Introduction}

The Early Christian Literature has identified a variety of interpretations of the term "religion", but also a frequency of their use. The term "religion" is interpreted as: (1) piety/fear of God; (2) a description of a particular religious tradition or teaching; (3) devotion or loyalty to higher beings through devotional acts; (4) ritual-worship; (5) true relig ion/superstition; (6) relig ious freedom; and (7) conceptual category (Gaitanos, 2017, pp. 87-124). Of course, the effort that evolved around the end of the 3rd century AD was of particular importance, when religion gradually began to be promoted as a conceptual category.

Of course, the central effort of most of the texts of the Early Christian Literature was the construction of the Christian identity, the treatment of accusations by the gentiles, and the clarification of specific points of Christian teaching that caused ambiguities and unrest (Johnson, 2006, p. 1; Rhee, 2005, pp. 20, 21; Cameron, 2002, pp. 219-227). But it would be interesting to study whether a more systematic attempt was made to study religion and the various cults of that time and whether it was based on a theoretical framework. Through the study of these texts, we found that the most systematic attempt to record, study, present, and evaluate the various religious traditions was attempted by Clement of Alexandria and Lactantius.

However, we appreciate that the most interesting statement related to the theory of study of religion comes from Arnobius, who by the phrase "Opinio religionem facit" (the opinion constructs religion) has

Georgios Gaitanos, Ph.D., lecturer of Religious Studies, Department of Social Theology \& Religious Science, College University Logos, Tirana, Albania.

1 Arnobius, Adversus Gentes, PL 5, Book VII, Chapter 37, p. 2. 
best justified not only the variety and the diversity of the various religions, but also that is relevant what each person regards as religious or not. It should be noted that his phrase seems to be prophetic, because when the scientific study of religion began to emerge from the 19th century onwards, when various approaches emerged from different schools, it seemed like religion and, above all, its scientific study was a creation of its scholars (Smith, 1982, p. 11). Creative thought and personal comparisons made by various scholars to form their arguments for analyzing a religious phenomenon and making generalizations was a predominant feature of academic scholars of religion (Smith, 1982, p. 11). Of course, Arnobius's statement at this point of his work was part of his effort to present the vanity of the cults and the sacrifices in honor of the various deities (Zarotiades, 2011, pp. 15-16), as he attempted to prompt the readers of his text to change their view of religion, but at the same time, it is probably the first statement that reflects the belief that religion is not just an expression of worship as it may be related to thinking, worldview and perception of things.

\section{Theoretical Context}

As we mentioned above, the purpose of the writers of the Early Christian Literature was not to form the theoretical background for the systematic study of religion as a phenomenon or of various cults, but to establish a way of highlighting Christian worship and overthrowing the "authenticity" of other cults. Also, these texts are not systematic studies or study manuals of various religions in modern perspective and form, but we appreciate that Clement's propitiatory tendency and Lactantius' apologetic direction can be approached as the first theoretical attempts of a comprehensive study of the religious phenomenon.

Clement of Alexandria, through his works, Paedagogus (Tutor), Protrepticus (Exhortation), and Stromata (Miscellanies), may not have a systematized structure and development of his study (Arampatzis, 2014, pp. 82-86; Papadopoulos, 1977, pp. 334-356; Christou, 2005, pp. 108-114; Kontogonos, 1851, pp. 340-398; Rankin, 2006, pp. 125-131; Itter, 2009, pp. 33-54), but we could characterize his work as a religious history of mankind, in which he gently seeks to present the course of the religious manifestations of the various nations under the guidance of Logos and within the plan of the salvation of mankind (Nikolakakes, 1984, pp. 34-39). His rich material includes all nations, Greeks, Jews, Persians, Egyptians, and all the teachings and cults. Emphasizing to the Greek philosophy seeks to highlight that it is a pedagogical material, similar to the content of the Old Testament, as it is a preparation for the acceptance of Christian faith ${ }^{2}$. Indeed, he stressed that in all nations anyone can distinguish through their texts the desire and expectation of God, since he created people in the same way ${ }^{3}$, while the notion that people of all ages and nations were included in the plan of the divine economy is characteristic ${ }^{4}$. Certainly, Christian truth and faith are perfect for Clement, but no one should be indifferent to those elements of Greek philosophy that try to approach the truth and can help Christians in its understanding ${ }^{5}$. Thus, Clement formed a unified religious history where the various stages and different religious views were a preparation for the appearance of Christian faith.

\footnotetext{
Clement of Alexandria, Stromata, Book 1, Chapter 28, p. 3.

${ }^{3}$ Clement of Alexandria, Protrepticus, Omilia A', Chapter 1, 5, 3. 1, 7, p. 3.

${ }^{4}$ Clement of Alexandria, Stromata, Book 6, Chapter $13^{\cdot} 6,41,5^{*} 7,9,1-12$, p. 5.

${ }^{5}$ Ibid, $1,26,1^{*} 1,28,1^{*} 1,98,4^{*} 6,117,1^{*} 6,160$, p. 1.
} 
On the other hand, Lactantius followed a different approach, as the removal of cultural features from the concept of "religio", as impressed by Cicero, helped shape religion as a distinct concept in contemporary Western thought. Indeed, this concept due to the approach of Lactantius gained more theological characteristics, since it was directly connected with the worship of one and true God, while he did not perceive any cultural elements (Schott, 2008, p. 106). In addition, the main tool in shaping his theoretical thought was the "true/false religion" dipole, as the concept religion was identified with the true religion, which was only Christianity. Thus, he developed an ecumenical concept where "religion" was identified only with Christianity, and Christianity was the model and example of what religion is (King, 1999, p. 37).

The definition of religion by Lactantius was an important conquest for the final construction of the term "religion" by theological or theological criteria, but also a means of separation with respect to the "others". Thus, those who worship the other deities are superstitious, while those who worship the true God belong to religion ${ }^{6}$. This dipole then constituted the decisive factor in classifying and studying religions and establishing "us/others" in the approach of different cultures (Smith, 1998, pp. 269-284). Thus, the term "religion" was used to describe one aspect of the culture of others as it transmits and indicates the criteria of classification of the Western world. The term religion appeared more as a symbol of distinction, separation, and apologetic tendencies. Our "religion", then, is the true one, while the religion of others is false religion, magic, or mere superstition. Substantially, the opinion for religions has always been moral, always based on the Western way of thinking and the Western view and concept of religion (Redfield, 1968, pp. 143-167; Segal, 2005, p. 1179). Concerning the distinction between the concept of "us" and "others" is that religion was treated as something unique, as something unrelated to other human activities or to any cultural environment. We realize, therefore, that religion was presented as a sui generis case, which valued only for the essence behind the "religious" things through a phenomenological approach of religions ${ }^{7}$ (McCutcheon, 2003).

Of course, with regard to the formation of this theoretical background through the "us/others" and "true/false religion" dipoles, we must not forget the political conditions under which these views were cultivated. In the case of Lactantius, the distinction between religio and superstitio, i.e., the true religion of a true God and the false cults of the various peoples, dates back to the period of major changes in the administration of the Empire. Also, the rationale of defining religion as a non-cultural ecumenical class was expressed in an empire characterized by national and cultural diversity. The use of his apologetic approach linked the illusory nature of religions with the different nations, and therefore, the discussion of religion at this time should always be related to the examination of ethnography and topography (Schott, 2008, p. 106).

\section{History of Religions}

It was expressed above the opinion that the two apologists used a different approach to presenting the historical evolution of the religions/cults up to their present times. We could, by analogy, name the work that they presented as a History of Religions or a religious history of mankind, but with very different preconditions

\footnotetext{
${ }^{6}$ Lactantius, Divinae Institutiones, PL 6, Book 4, Chapter 28, p. 16.

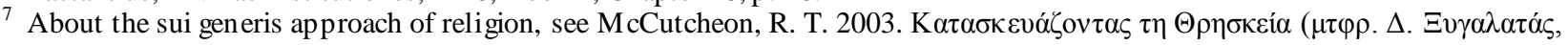

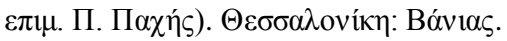


and objectives in relation to the modern branch and the modern concept of History of Religions ${ }^{8}$ (Bianchi, 1975 , p. 5). Besides, when they wrote, they functioned as apologists and defenders of a particular religious tradition, and in no case worked for scientific purposes according to a particular methodology of academic study of religion. However, the way they attempted to present, for the first time in relation to the other apologists, the religious history of mankind up to their times, could be considered as such an enterprise. Moreover, many of the earliest scholars of religion at the academic level attempted the classifications and the presentation of the various religious traditions based on the criteria of their Christian faith (Gaitanos, 2016, pp. 33-34).

It is clear, therefore, that there are two different trends and approaches, but they have come to the same conclusion, namely that Christianity is the perfect and true worship. Clement presented a set of works with a more protreptic and less aggressive attitude to philosophy and other cults in relation to his predecessors, highlighting Christianity as the ultimate result in the search for mankind for truth and God. The various worshiping traditions and teachings have been dealt with as a progressive process, which tried to seek God, but eventually they did not succeed, as Christian teaching did. Indeed, many of these teachings, according to him, such as Greek philosophy and the Old Testament, had some common elements, influences were observed between them and could be considered as preparation for the acquaintance and know ledge of the complete truth by mankind through Christianity. Possibly, this model of presentation of various cults reminds of a potential theory of diffusion and cultural loans ${ }^{9}$ (Ziakas, 2002, pp. 110-111; Martin, 2003, p. 103; Sharpe, 2008, pp. 325-331; Evans-Pritchard, 1987, pp. 67-68; Levi-Strauss, 1991, p. 34; Erickson \& Murphy, 2002, p. 77).

Clement gave emphasis to the presentation of Greek philosophy and Greek mystical cults, getting information either from works of ancient Greek literature (poetry, philosophy, and works of religious content) or from personal observation and experience. It is characteristic that he made fewer references to the cults of the Egyptians, the Phrygians, the Indians, and the Persians, not because he underestimated them but because he preferred to present more data about the cults he knew personally. In general, he did not give a detailed presentation of the institutions and characteristics of the cults of other nations, but he supported his argumentation on specific issues that served the apologetic purpose of his works. For example, he has extensively used the theory of Euhemerus (euhemerism) (Roubekas, 2011) and of Theodore of Cyrene, in order to draw data to overthrow the belief that the gods of the Greeks and other nations actually had a divine

\footnotetext{
${ }^{8}$ In general, the science of History of Religion examines the historical evolution of religions, studying their sources, their teaching, and their course at the end of history. What characterizes this branch of the study of Religion is the dialectic re lationship between the subject and the methods of its research. It is the historical science that studies through time the phenomena we call religious. Each of them has its peculiarity as it exerts a different influence over other religious phenomena that may occur in the same space. Thus, religions are investigated as historical processes, as complexes of doctrine and deeds, as systems. These systems, on the one hand, respond to human behavior, religious behavior, on the other hand, however, seems to have significant differences, leading to the development of questions about their historical categorization. Essentially, religion is consider ed as a system where it is investigated whether religious beliefs and religious institutions are changing and are in constant interaction with social reality. Thus, the relationship of religion with different realities, such as society, economy, politics, and culture, is examined, but also what situations are formed in the religious context within the historical context.

9 It is an evolutionary theory of the Pan-Babylonian School, which argued that the similarities observed between cultures of different regions should be attributed to the diffusion from an original source, the region where these common features were born. Due to migrations or other contacts, a similar theory was supported in the so-called faculty of "circles of culture", i.e., the view that common or similar elements that may be found in the same geographic area are due to small-scale lending, contacts and migration within that area. However, the supporters of diffusion theory usually assumed that cultural discoveries could not be made independently in different regions, and therefore diffusion from a single original site was necessary to appear later in different regions. This view states that evolution and progress is the privilege of a single culture.
} 
existence (Nikolakakes, 1984, pp. 41-48). Therefore, his works should not be treated as an objective presentation of the others, despite accepting the positive characteristics of their teaching, but as an alternative apologetic effort to promote the superiority of Christian worship.

On the other hand, Lactantius followed a more aggressive attitude in his apologetics, because through the depreciation of the cultural characteristics of the various teachings, he emphasized the absolute and unique truth of one God, giving religion exclusively theological characteristics. The "true/false religion" dipole demeans the cultural features and peculiarities of each tradition, resulting that the discussion was being limited to the worship of God. God is one and therefore religion is one. Whatever else does not fall into these characteristics, it cannot be considered a religion. The apologetic dimension of Lactantius' work can be summarized as a history of true religion and false cults. The history of religions of Lactantius places at the top an authentic and original proto-monotheism $^{10}$ (Ziakas, 2002, p. 118; Eggan, 1972, pp. 131-132; Evans-Pritchard, 1972, pp. 31-32; Morris, 1987, p. 102; Erickson \& Murphy, 2002, pp. 79-80), which in the course of history, was disturbed and lost. The reference and presentation of the various cultures and cults of the Romans, Greeks, Egyptians, and Jews is carried out in such a way that it establishes a historical distinction between authentic and pure monotheism or true religion (vera religio) and the variety of national cults or false cults (falsae religiones). True religion is ancient and eternal, while national cults are the product of culture and national diversity (Schott, 2008, pp. 96-97).

According to Lactantius, these new national religions have emerged since people began to form separate communities under the guidance of their leaders and heroes. All the false religions were essentially "national", with some of them gaining greater acceptance, and others remaining at the local level ${ }^{11}$. Therefore, he directly links the birth of nations to the beginning of religion. A distinct group of people always develops a new religion, resulting according to Lactantius that religion and nation are the same, since each ethnic group has its religion as well. Thus, the history of religions of Lactantius resembles an ethnographic research, as he dedicates much of his work to the topographical (geographical) origin of each cult (Schott, 2008, pp. 97-98). Of course, these cults placed within the framework of human history are considered to be false. On the other hand, true religion is placed beyond the history of human civilization and out of time. The beginning of true worship cannot be traced back to the historic period, since true religion is not a human cultural product, but a divine one and outside of this world ${ }^{12}$.

\section{Conclusions}

In conclusion, we can see that the subject of "religion" to both writers was linked to national and cultural characteristics, which reveals that what people of this era perceived as a religion was related to their cultural habits and their national/relig ious identity. On the one hand, Clement accepted the contribution of the various cultures to the search for the divine as part of the plan of the divine economy, while on the other hand, Lactantius rejected the cultural diversification in the search and worship of the divine as he believed that religion was delivered to man from a superior ontological reality and was not a product of human epiphany.

\footnotetext{
10 According to the theory of "proto-monotheism" (Ur-Monotheismus), there was a pre-existence of faith in a superior being who created the world and then moved away from it. It is considered as a kind of Monotheism, which preceded Polytheism.

${ }^{11}$ Lactantius, Divinae Institutiones, PL 6, Book 1, Chapter 15, pp. 7-10.

12 Lactantius, Divinae Institutiones, PL 6, Book 3, Chapter 16, p. 10.
} 


\section{References}

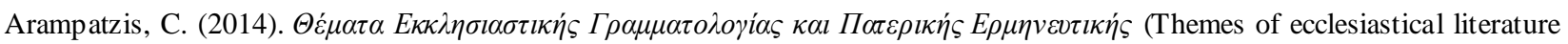
and hermen eutics of the fathers). Thessaloniki: Ostracon Publishing.

Bianchi, U. (1975). The history of religions. Leiden: Brill.

Bowen, A., \& Garnsey, P. (2003). Lactantius-Divine Institutes. Liverpool: Liverpool University Press.

Cameron, A. (2002). Apologetics in the Roman Empire-A genre of intolerance? Humana Sapit: Etudes d'antiquite tardive o Vertes a Lellia Cracco Ruggini, L'Antiquite' Tardive, 3, 219-227.

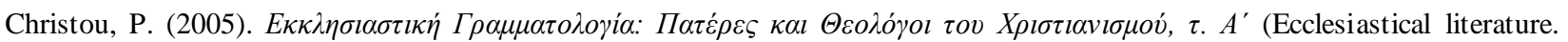
Fathers and theologians of Christianity, Vol. I). Thessaloniki: Kyromanos.

Eggan, F. (1972). One hundred years of ethnology and social anthropology. In J. O. Brew (Ed.), One hundred years of anthropology (pp. 119-149). Cambridge: Harv ard University Press.

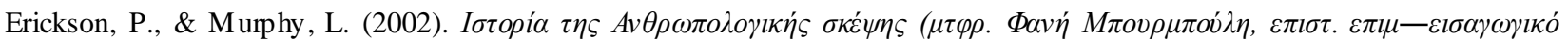

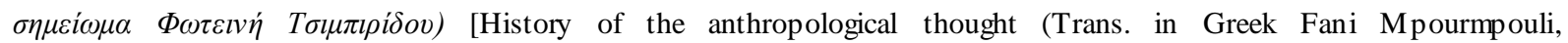
editor-introduction by Foteini Tsimpiridou)]. Athens: Kritiki.

Evans-Pritchard, E. E. (1972). Theories of primitive religion. Oxford: Oxford University Press.

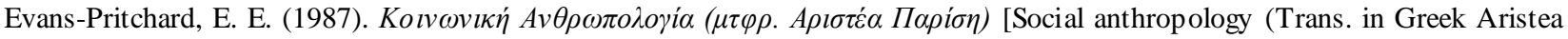
Parisi)]. A $\theta \dot{v} \alpha \alpha: K \alpha \rho \delta \alpha \mu i ́ \tau \sigma \alpha$.

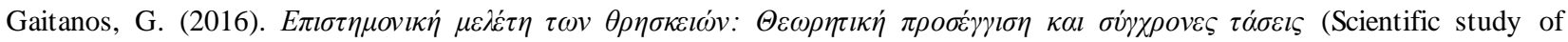
religions: Theoretical procedure and modern tendencies). Thessaloniki: Barbounakis Publishing.

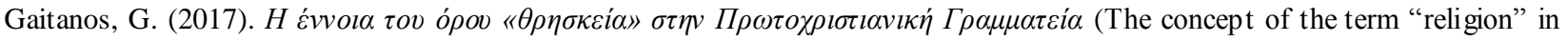
early Christian literature). Thessaloniki: Ostracon.

Itter, A. (2009). Esoteric teaching in the Stromate is of Clement of Alexandria. Leiden: Brill.

Johnson, A. (2006). Ethnicity and argument in Eusebius' Praeparatio Evangelica. Oxford: Oxford University Press.

King, R. (1999). Orientalism and religion: Postcolonial theory, India and "The Mystic East”. London: Routled ge.

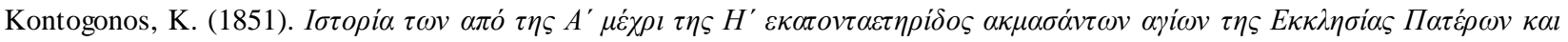

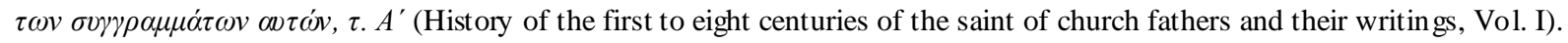
Athens: S. K. Vlastos.

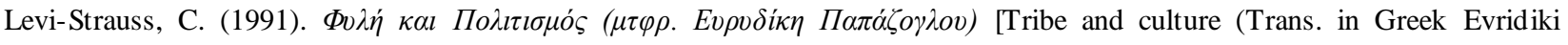
Papazoglou)]. Athens: Gnosi.

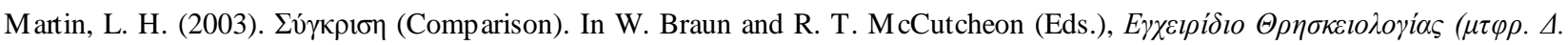

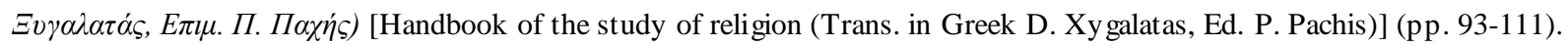
Thessaloniki: Vanias.

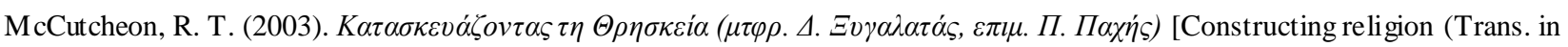
Greek D. Xy galatas, Ed. P. Pachis)]. Thessaloniki: Vanias.

Migne J. P. (1841). Patrologiae Cursus Completus: Sive Biblioteca Universalis, Integra, Uniformis, Commoda, Oeconomica, Omnium SS. Patrum, Doctorumscriptorumque Eccelesiasticorum Qui Ab Aevo Apostolico Ad UsqueInnocentii III Tempora Floruerunt (Full version of patrology). Paris: Migne.

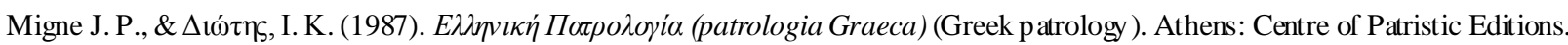
Morris, B. (1987). Anthropological studies of religion: An introduction. Cambridge: Cambridge University Press.

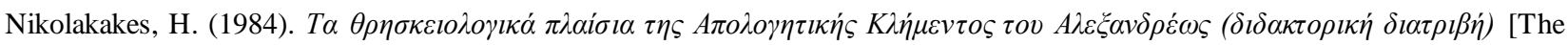
religious framework of the Apologetics of Clement of Alexandria (dissertation thesis)]. Thessaloniki: Patriarchal Institution of Patristic Studies.

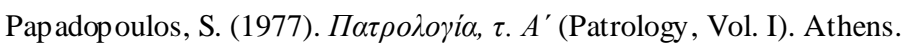

Rankin D. (2006). From Clement to Origen: The social and historical context of the church fathers. Hamp shire: Ashgate.

Redfield, R. (1968). The primitive world and its transformations. Harmondsworth: Pengu in Books.

Rhee, H. (2005). Early Christian literature: Christ and culture in the second and third centuries. London: Routled ge.

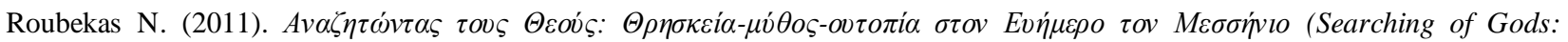
Religion-Myth-Utopia in Euhemerus of Messini). Thessaloniki: Vanias.

Schott, J. (2008). Christianity, empire, and the making of religion in late antiquity. Philadelphia: University of Pennsylvania Press. 
Segal, R. (2005). Classification and comparison in the study of religion: The work of Jonathan Z. Smith. AAR, 73(4), 1175-1188.

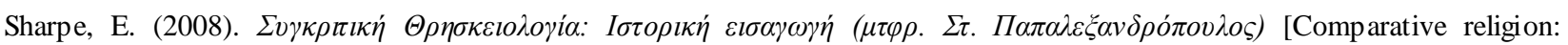
Historical introduction (Trans. in Greek St. Papalexandropoulos)]. Athens: Artos Zois.

Smith, J. Z. (1982). Imagining religion: From Babylon to Jonestown. Chicago: Chicago University Press.

Smith, J. Z. (1998). Religion, religions, religious. In M. C. Taylor (Ed.), Critical terms for religious studies (pp. 269-284). Chicago: The University of Chicago Press.

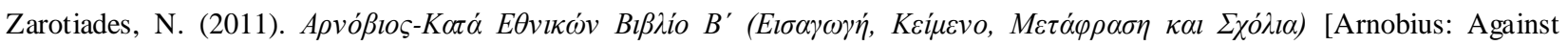
gentiles (Introduction, text, translation and comments)]. Thessaloniki: Ostracon Publishing.

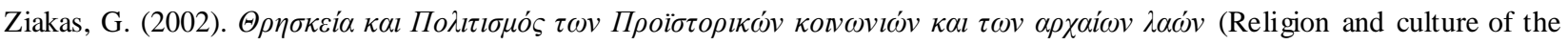
pre-historic societies and ancient people). Thessaloniki: Kornelia Sfakianaki. 